\title{
MORPHOMETRIC DIFFERENCES BETWEEN SOUTH AMERICAN AFRICANIZED AND SOUTH AFRICAN (APIS MELLIFERA SCUTELLATA) HONEY BEES
}

\author{
Steven M. BUCO *, Thomas E. RINDERER **, H. Allen SYLVESTER **, \\ Anita M. COLLINS ${ }^{* *}$, Vicki A. LANCASTER * and Robin M. CREWE *** \\ with the technical collaboration of G. Lorraine DAVIS ${ }^{* *}$ and Daniel WINFREY ${ }^{* *}$ \\ * Department of Experimental Statistics, Louisiana State University, \\ Baton Rouge, Louisiana 70893, U.S.A. \\ ** United States Department of Agriculture, Agricultural Research Service, \\ Honey-Bee Breeding, Genetics, and Physiology Laboratory, \\ 1157 Ben Hur Road, Baton Rouge, Louisiana 70820, U.S.A. \\ ${ }^{* * *}$ Department of Zoology, University of Witwatersrand, \\ 1 Jan Smuts, Johannesburg, 2001, South Africa
}

\begin{abstract}
SUMMARY
Univariate statistical analysis and multivariate discriminant analysis were conducted for 25 morphological characteristics of a sample of South African Apis mellifera scutellata and of a sample of feral South American honey bees. The two populations differed for 19 of 24 characteristics, with the bees from Africa also being consistently smaller. The discriminant function completely separated the two populations. The Africanized bees in this study were quite similar to those in a large survey by DALY and Balling (1978) which found South American Africanized bees to be distinctly different and smaller than European bees. Thus, the feral bees of South America clearly show the influence of both their European and their African parentage although they are more similar to their African parents.
\end{abstract}

\section{INTRODUCTION}

Understanding the process of Africanization and developing approaches to prevent it require a clear understanding of the genetic nature of Africanized populations. TAYLOR (1985) believes that the Africanized bees of South America are more appropriately described by the nomen "African » rather than «Africanized». However, certain differences between the feral bees of South America and the parental Apis mellifera scutellata (formerly A. m. adansoni, RUTrNeR, 1986) stock in Africa suggest that Africanized bees may fit KING's (1968) definition of a "hybrid swarm » at the subspecific level (RINDERER, 1986). 


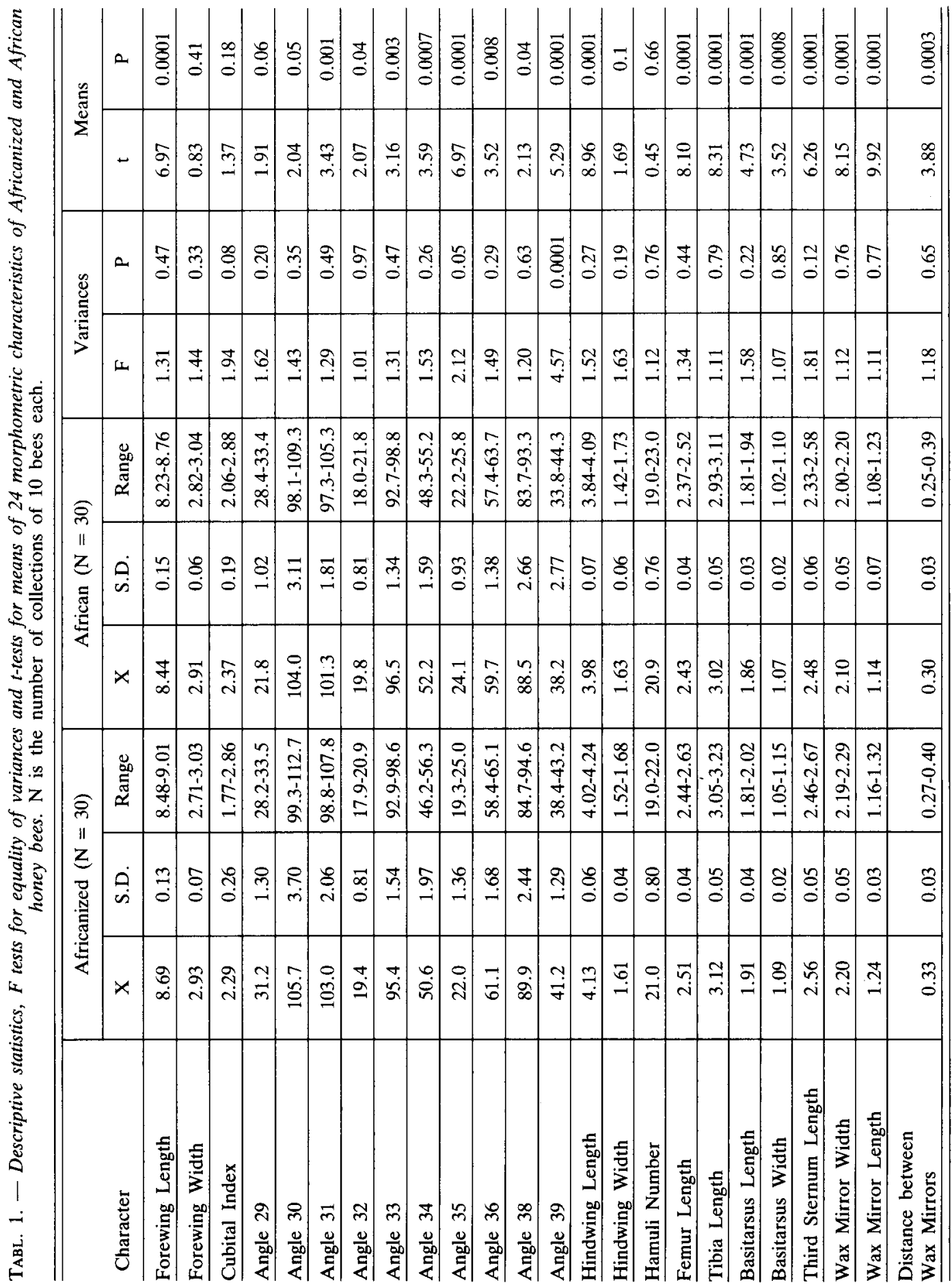


In order to clarify the origin of the feral bees of South America we compared the morphology of a collection made in Venezuela with a collection of $A$. m. scutellata representatives from South Africa.

\section{MATERIALS AND METHODS}

Swarms of feral honey bees were collected and sampled in west-central Venezuela in areas surrounding Acarigua. Samples of worker bees were taken either when a swarm was collected or after a swarm was established as a colony with naturally occurring comb cell sizes in its brood nest. Thirty swarms were sampled; each sample consisted of 10 worker bees.

Kept colonies of African bees from caught swarms supplied 30 samples of 10 worker bees each. Of these 30 African colonies, 10 came from near Johannesburg, and 20 came from western Transvaal. All of these colonies came from apiaries in the general location which supplied the majority of the African parental stock of the feral bees of South and Central America (KerR, 1957). Frames contained comb produced by the bees from starter strips. Presumably, both the bees imported by KerR (1957) and the bees in this study are samples of $A . m$. scutellata.

All samples were measured morphometrically according to the computer-assisted procedures outlined by Daly et al. (1982). Twenty-five separate measurements were made (Table 1) on each of 10 bees for each sample.

Sample means were calculated for each measurement and the "cubital index " was calculated as the average of ratios between vein $M$ proximal and distal abscissa lengths. Sample means were used to estimate population means and variances and to determine if differences existed between population means with t-tests. The equalities of variances were assessed using F-tests.

The 24 measurements were then used to compare the two groups of honey-bee samples using multivariate discriminant analysis $\left(\operatorname{SPSS}^{\mathrm{X}}(1), 1983\right)$. All sixty samples were used to first develop a discriminant function and then to evaluate it.

\section{RESULTS}

Africanized bees from South America differed significantly $(\mathrm{P}=0.05$ or less) from African bees (A. m. scutellata) for 19 of the 24 characteristics analyzed by t-tests (Table 1 ). Africanized bees were consistently larger than African bees. The variances of the two groups were generally similar ; a strong difference in variance occurred only for measurements of angle 39. For these measurements African bees had a larger variance $(P<0.0001)$.

The differences found in comparisons of individual characteristics are reflected in the multivariate discriminant function analysis. The two populations were completely separated by the discriminant function (Fig. 1). The posterior probability of group membership for all cases indicated a correct classification of $\mathbf{P}=0.9984$ or greater using the derived discriminant function.

(1) SPSS, Inc., Chicago, Illinois. Use of a corporation name does not constitute an endorsement by the U.S. Department of Agriculture. 


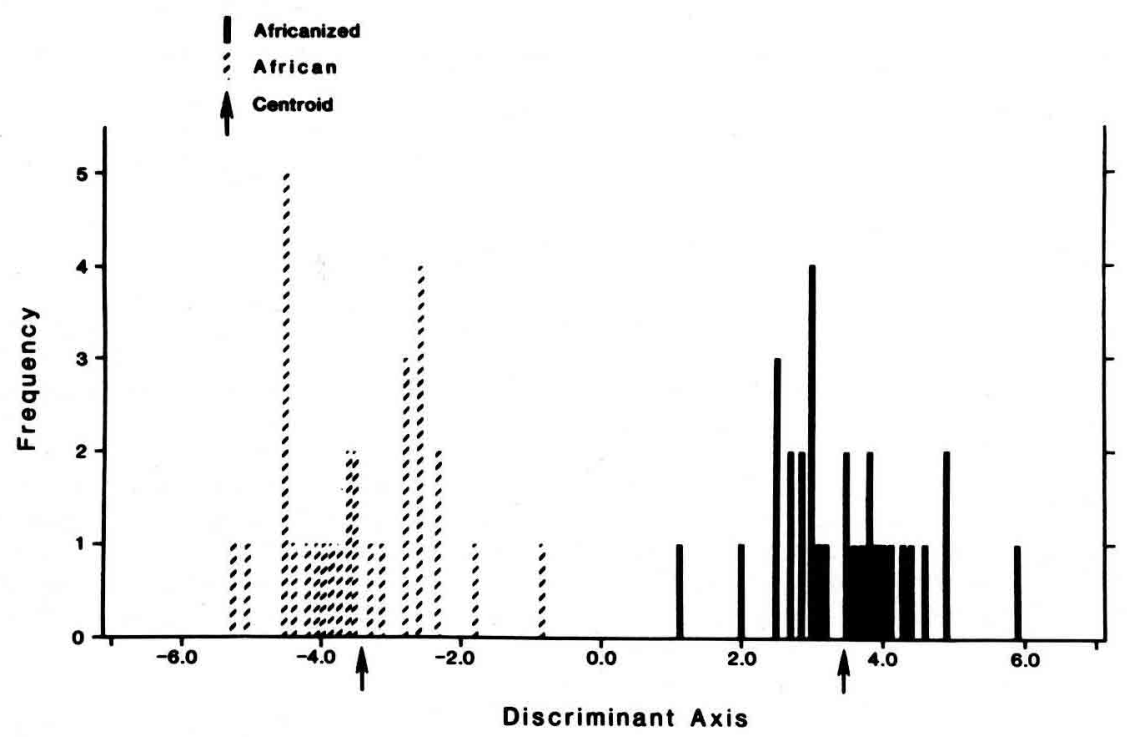

Fig. 1. - Histogram of the results of the multivariate discriminant function analyses of African and Africanized bees.

\section{DISCUSSION}

Clearly, the feral bees of South America now constitute a population which is morphometrically quite different from the parental population of $A$. $m$. scutellata in Southern Africa. Comparisons of individual characteristics as well as the composite analysis represented by the discriminant function indicate that Africanized bees are generally larger than their African parental stock. Comparing these data to those of DALY and BALLiNG (1978), our sample of Africanized bees was practically identical to their sample of Africanized bees. Thus, all Africanized bees (those studied by DALY et al., loc. cit. as well as the current survey) have morphology which is intermediate between that of African and European stock. However, 18 of the 24 measurements are more similar to African bees than they are to European bees.

The most likely explanation for these differences is that Africanized bees in the Americas are a subspecific hybrid swarm (KING, 1968) which has resulted from matings with European bees and the subsequent crossing and backcrossing. The generally intermediate morphometric character of Africanized bees suggests that a large number of loci are involved in the determination of the honey bee's morphometric make up. Predictable Mendelian events associated with crossing and then backcrossing between African and 
European bees would produce the Africanized bees that we have measured. Such bees clearly show the influence of both their European and their African parentage.

Because of the hybrid nature of Africanized bees, predictions concerning their potential behavior in North America based on extrapolations from African bees are probably unrealistic. Genetic events within the population of Africanized bees may lead to combinations and levels of characteristics not present in either parental population. Thus, defensive behavior, foraging and honey production, pollination and overwintering abilities, and potential range are best determined experimentally.

Received for publication in September 1986. Accepted for publication in December 1986.

\title{
ACKNOWLEDGEMENT
}

In cooperation with the Louisiana Agricultural Experiment Station.

\author{
RÉSUMÉ \\ DIFFÉRENCES MORPHOMÉTRIQUES \\ ENTRE LES ABEILLES AFRICANISÉES D'AMÉRIOUE DU SUD \\ ET LES ABEILLES D'AFRIQUE DU SUD (APIS MELLIFICA SCUTELLATA)
}

Comprendre le processus d'africanisation des populations d'abeilles des Amériques implique de comprendre clairement la nature génétique des abeilles sauvages d'Amérique du Sud. Afin d'éclaircir l'origine des abeilles sauvages d'Amérique du Sud, nous avons comparé la morphologie d'abeilles provenant de 30 essaims récoltés au Vénézuéla avec celle d'abeilles provenant de 30 colonies d' $A$. $m$. scutellata d'Afrique du Sud.

Les mesures morphométriques ont été faites selon les procédés informatisés décrits par DaLY et al. (1982). Les moyennes des échantillons ont été utilisées pour estimer les moyennes et les variances de la population et pour déterminer à l'aide de tests-t s'il existait des différences entre les moyennes de la population. On a ensuite utilisé les 24 mesures pour comparer les deux groupes d'échantillons d'abeilles à l'aide de l'analyse discriminante multivariable.

Les abeilles africanisées d'Amérique du Sud diffèrent de façon significative des abeilles africaines pour 19 des 24 caractères étudiés (Tabl. 1). Les abeilles africanisées sont uniformément plus grandes que les africaines. Les deux populations ont été totalement séparées par la fonction discriminante. Si l'on compare ces données avec celles de Dally et BaLing (1978), on se rend compte que notre échantillon d'abeilles africanisées ont une morphologie intermédiaire entre celle de la souche africaine et celle de la souche européenne. Néanmoins 18 caractères, parmi les 24 , sont plus proches des abeilles africaines que des abeilles européennes.

Les abeilles africanisées reflètent nettement l'influence de leur double parenté, européenne et africaine. En ce sens, elles correspondent à la définition de l'essaim hybride subspécifique (KING, 1968). En raison de la nature hybride des abeilles africanisées, il n'est probablement pas réaliste d'extrapoler à partir des abeilles africaines pour prédire leur comportement potentiel. 


\section{ZUSAMMENFASSUNG \\ MORPHOMETRISCHE UNTERSCHIEDE ZWISCHEN AFRIKANISIERTEN BIENEN IN SÜDAMERIKA UND DEN BIENEN VON SÜDAFRIKA (APIS MELLIFERA SCUTELLATA)}

Um den Prozess der Afrikanisierung der Bienen in den beiden Amerikas zu verstehen, ist eine klare Kenntnis der genetischen Zusammensetzung der wildlebenden Bienenvölker in Südamerika erforderlich. (Es gibt in Südamerika unglaublich zahlreiche wilde Bienenvölker und herumziehende Schwärme, alles Nachkommen einiger importierter Königinnen aus Südafrika, gewöhnlich als « afrikanisiert » bezeichnet. Die früher vorhandenen, aus Europa stammenden Bienen sind fast völlig verschwunden. Anm. d. Redaktion).

Um die Herkunft der wildlebenden Bienen von Südamerika aufzuklären, haben wir die Körpermerkmale von 30 Schwärmen aus Venezuela mit Bienen aus 30 Völkern von $A$. $m$. scutellata aus Südafrika verglichen. Die Proben wurden morphometrisch nach dem computerisierten Verfahren gemessen, wie es von Daly et al. (1982) beschrieben wurde. Die Mittelwerte der Proben wurden als Schätzwert für Mittelwert und Varianz der Völker benutzt, um dann mit Hilfe des t-Testes zu bestimmen, ob Unterschiede zwischen den Mittelwerten der Populationen bestehen. Es wurden 24 Merkmale gemessen, die in einer multivariaten Diskriminanzanalyse ausgewertet wurden.

Die Afrikanisierten Bienen aus Südamerika waren in 19 von den 24 gemessenen Merkmalen signifikant von den afrikanischen Bienen verschieden (Tab. 1). Die Afrikanisierten Bienen waren deutlich größer als die afrikanischen. Die beiden Populationen wurden durch die Diskriminanzfunktion vollständig getrennt. Bei einem Vergleich unserer Daten mit denen von Daly und Balling (1978) zeigte sich, daß ihre Daten von Afrikanisierten Bienen mit unseren völlig übereinstimmten. Es nehmen also alle Afrikanisierten Bienen in ihren Außenmerkmalen eine Mittelstellung zwischen afrikanischen und europäischen Bienen ein. Aber 18 von den 24 Meßwerten sind ähnlicher den afrikanischen als den europäischen Bienen.

Die Afrikanisierten Bienen zeigen klar den Einfluß sowohl ihrer europäischen wie ihrer afrikanischen Vorfahren. Damit entsprechen sie der Definition eines Hybridschwarmes innerhalb der Art (KING, 1968). Wegen der Hybridnatur der Afrikanisierten Bienen sind wahrscheinlich Voraussagen über ihr mögliches Verhalten, ausgehend von einer Übertragung der Erfahrungen mit afrikanischen Bienen, unrealistisch.

\section{REFERENCES}

Dal. H.V., Balling S.V., 1978. - Identification of Africanized honey bees in the Western Hemisphere by discriminant analysis. J. Kansas Entomol. Soc., 51, 957-969.

Daly H.V., Hoelmer K., Norman P., Allen T., 1982. - Computer-assisted measurement and identification of honey bees (Hymenoptera : Apidae). Anm Entomol. Soc, Amer., 75, 591-594.

Kerr W.E., 1957. - Introdução de abellas africanas do Brasil. Brasil Apic., 3, 211-213.

KING R.C., 1968. - A Dictionary of Gemesics. Oxford Univ. Press, New York, p. 124.

Rinderer T.E, 1986. - Africanized Bees: The Africanization prosess and their potential range in the United States. Bull. Entomot. Soc. Amer., 32, 222, 224, 226-227.

RUTrNer F., 1986 - Geographical variability and classification. In : Bee Genetics and Breeding, T.E. Rinderer, ed. Academic Press, Orlando (Florida), 23-56.

SPSS ${ }^{X}$, 1983. - SPSS ${ }^{X}$ Users Guide. SPSS Inc., Chicago, Illinois.

TAYLoR O.R., 1985. - African bees: Potential impact in the United States. Bult. Entomol. Soc. Amer., 31, $15-24$. 